Professor Guangshun Jiang of the state forestry feline research centre, Fuyou Wang and Quan Sun of the Wangqing forestry bureau and several others for help in the field.

Quanhua Shi, Qi Li and Minghai Zhang College of Wildlife Resources, Northeast Forestry University, Harbin, Heilongjiang, China

E-mail zhangminghai2004@126.com

\section{Going, going....narrowly endemic snails in Malaysia at imminent risk of extinction as a result of quarrying}

Isolated limestone hills are well known for the remarkable micro-endemism among many of the animals living on them, or in their caves. Species can be found in just one cave or on just one hill-and nowhere else. What has not been done recently is to engage the companies that are quarrying these hills for the manufacture of cement. The larger cement companies do give some attention to biodiversity, but a trawl through their websites shows that this attention is focused almost entirely on the rehabilitation or restoration of sites-typically the creation of wetlands from the pits left after the hill has disappeared into brown sacks.

There was press coverage in late 2014 when a new species of snail, Charopa lafargei, was named for Lafarge, the multinational cement company that is quarrying the only hill where it is known in Malaysia. There was also attention given in the latest Red List to another snail species that is now categorized as Extinct because of cement quarrying. Also in Malaysia are limestone hills that are being quarried by the international Malaysian conglomerate YTL (the owners of Wessex Water in the UK). One of these, Tenggek Hill, is the only known site for three species of unusual snail: the elephant trunk snail Hypselostoma elephas, Tenggek braided snail Plectostoma tenggekensis and towered braided snail Plectostoma turriforme, which is also know from the nearby Sagu Hill. But that is also being converted into a pit by YTL. These three species have recently been categorized on the IUCN Red List as Critically Endangered. The only natural habitat remaining for them on Tenggek Hill are two tufts of forest on the top. Tenggek and Sagu Hills are also the only known localities for the attractive herb Paraboea bakeri, and the fern Calciphilopteris alleniae is known from Tenggek Hill and just four other sites (all in Peninsular Malaysia).

IUCN has written to the CEO of the company in Kuala Lumpur asking for the company's assurance that they will avoid the imminent extinction of these species, and offering assistance with conservation planning.

TONY WhITTEN Fauna \& Flora International, Cambridge, UK E-mail tony.whitten@fauna-flora.org 